\title{
Placental Vasculogenesis Is Regulated by Keratin-Mediated Hyperoxia in Murine Decidual Tissues
}

\author{
Cornelia Kröger, ${ }^{\star \dagger}$ Preethi Vijayaraj, ${ }^{* \ddagger}$ \\ Ursula Reuter, ${ }^{*}$ Reinhard Windoffer, ${ }^{\S}$ \\ David Simmons, "Lukas Heukamp," \\ Rudolf Leube, ${ }^{\S}$ and Thomas M. Magin*† \\ From the Division of Cell Biochemistry," Institute of Biochemistry \\ and Molecular Biology, and the Institute of Pathology," University \\ of Bonn, Bonn, Germany; the Institute of Biology and \\ Translational Center for Regenerative Medicine, ${ }^{\dagger}$ University of \\ Leipzig, Leipzig, Germany; the Centre for Vascular Biology \\ Research, ${ }^{\ddagger}$ Department of Medicine, Beth Israel Deaconess \\ Medical Centre, Harvard Medical School, Boston, Massachusetts; \\ the Institute of Molecular and Cellular Anatomy, ${ }^{\S}$ RWTH Aachen \\ University, Aachen, Germany; and the School of Biomedical

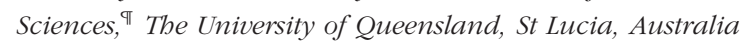

The mammalian placenta represents the interface between maternal and embryonic tissues and provides nutrients and gas exchange during embryo growth. Recently, keratin intermediate filament proteins were found to regulate embryo growth upstream of the mammalian target of rapamycin pathway through glucose transporter relocalization and to contribute to yolk sac vasculogenesis through altered bone morphogenetic protein 4 signaling. Whether keratins have vital functions in extraembryonic tissues is not well understood. Here, we report that keratins are essential for placental function. In the absence of keratins, we find hyperoxia in the decidual tissue directly adjacent to the placenta, because of an increased maternal vasculature. Hyperoxia causes impaired vasculogenesis through defective hypoxia-inducible factor $1 \alpha$ and vascular endothelial growth factor signaling, resulting in invagination defects of fetal blood vessels into the chorion. In turn, the reduced labyrinth, together with impaired gas exchange between maternal and embryonic blood, led to increased hypoxia in keratin-deficient embryos. We provide evidence that keratin-positive trophoblast secretion of prolactin-like protein a (Prlpa) and placental growth factor (PIGF) during decidualization are altered in the absence of keratins, leading to increased infiltration of uterine natural killer cells into placental vicinity and increased vascularization of the maternal decidua. Our findings suggest that keratin mutations might mediate conditions leading to early pregnancy loss due to hyperoxia in the decidua. (Am J Pathol 2011, 178:1578-1590; DOI: 10.1016/j.ajpath.2010.12.055)

Epithelial cells line the surface of internal organs and tissues. They provide mechanical support and protection from the external environment but are contemporaneously essential for the communication and the exchange of nutrients and oxygen from the environment, as in the gut and lung tissue, respectively.

The intermediate filament system of the epithelial cytoskeleton, formed by members of the keratin multiprotein family, is particularly suited to fulfill these functions. Keratins have been confirmed to provide mechanical stability, as diverse skin mutations account for. ${ }^{1-4}$ In addition, keratins have been shown to exert important signaling functions in an isotype- and context-dependent manner in epithelial cells. Previous mutation and knockout (KO) studies showed their involvement in the regulation of cell cycle, in protein translation through 14-3-3 proteins and the mammalian target of rapamycin complex, modulation of apoptotic signals, organelle transport and protection against metabolic stress. ${ }^{5-9}$ The functional analysis of individual keratins has been obscured by compensatory expression of other keratins expressed in the same epithelia. The recently reported deletion of all keratins in mice provided unexpected and novel insights into keratin function during mouse development. ${ }^{10}$ It showed that keratins play an essential role in embryogenesis, because mutant embryos died at embryonic day (E) 9.5 in midgestation because of severe growth retardation, caused by a drastic decrease in protein biosynthesis. This was due to a mislocalization of the glucose

Supported partially by the Deutsche Forschungsgemeinschaft (German Research Council) through SFB 832, A5, and MA-1316/9-3, and in part by Bonfor (Research group cytoskeleton), Thyssen Stiftung, and Bonner Forum Biomedizin.

Accepted for publication December 30, 2010.

Supplemental material for this manuscript can be found at $h$ ttp://ajp. amjpathol.org or at DOI:10.1016/j.ajpath.2010.12.055.

Address reprint requests to Thomas M. Magin, Ph.D., Institute of Biology and TRM, University of Leipzig, Philipp-Rosenthal-Str. 55, Leipzig 04103, Germany. E-mail: thomas.magin@trm.uni-leipzig.de. 
Table 1. Mouse Mutants of Epithelial Trophoblast Cells with Similar Phenotypes

\begin{tabular}{|c|c|c|c|c|}
\hline Gene & Gene product & $\begin{array}{c}\text { Expression pattern in placental } \\
\text { tissue and yolk sac }\end{array}$ & Mutant phenotype & Reference \\
\hline ARNT (Hif1 $\beta)$ & $\begin{array}{l}\text { bHLH/PAS transcription } \\
\text { factor }\end{array}$ & $\begin{array}{l}\text { Placental trophoblasts, trophoblast giant } \\
\text { cells }\end{array}$ & $\begin{array}{l}\text { Growth retardation at E9.5, } \\
\text { defective placental and yolk sac } \\
\text { vascularization }\end{array}$ & 17,24 \\
\hline$C \times 26$ & Connexin & Yolk sac epithelium, syncytiotrophoblast & Small labyrinth & 21 \\
\hline FGFR2 & $\begin{array}{l}\text { Fibroblast growth factor } \\
\text { receptor }\end{array}$ & Trophoblast cells & $\begin{array}{l}\text { Small labyrinth layer, reduced } \\
\text { vascularization, block of } \\
\text { trophoblast cell proliferation }\end{array}$ & 29 \\
\hline Fzd5 & Wnt receptor & Labyrinth trophoblast, yolk sac & $\begin{array}{l}\text { Reduced vascularization of yolk } \\
\text { sac and placenta }\end{array}$ & 22 \\
\hline $\begin{array}{l}\text { Hif1 } \alpha \text { and } \\
\quad H i f 2 \alpha\end{array}$ & $\begin{array}{l}\text { Hypoxia-inducible } \\
\text { factors }\end{array}$ & Placenta, yolk sac & $\begin{array}{l}\text { Reduced placental vascularization, } \\
\text { differentiation regulation of TGC } \\
\text { and spongiotrophoblast }\end{array}$ & 20 \\
\hline HSP90 & Heat shock protein & Labyrinth trophoblast, yolk sac & $\begin{array}{l}\text { Small labyrinth layer, reduced } \\
\text { vascularization }\end{array}$ & 23,28 \\
\hline JunB & $\begin{array}{l}\text { Transcription factor of } \\
\text { the AP-1 family }\end{array}$ & Trophoblast derivatives & $\begin{array}{l}\text { Small labyrinth layer, defective } \\
\text { placental and yolk sac } \\
\text { vascularization }\end{array}$ & 26 \\
\hline p38 & $\begin{array}{l}\text { Mitogen-activated } \\
\text { protein kinase }\end{array}$ & $\begin{array}{l}\text { Diploid trophoblasts, Labyrinth } \\
\text { trophoblast }\end{array}$ & $\begin{array}{l}\text { Reduced vascularization of yolk } \\
\text { sac and placenta }\end{array}$ & 25 \\
\hline PPAR $\gamma$ & $\begin{array}{l}\text { Nuclear hormone } \\
\text { receptor, ligand } \\
\text { activated } \\
\text { transcription factor }\end{array}$ & Diploid trophoblast lineage & $\begin{array}{l}\text { Reduced vascularization of } \\
\text { placenta, impaired differentiation } \\
\text { of syncytiotrophoblast }\end{array}$ & 18,19 \\
\hline Tfeb & $\begin{array}{l}\text { Transcription factor of } \\
\text { the bHLH zipper } \\
\text { family }\end{array}$ & Labyrinth trophoblast & $\begin{array}{l}\text { Reduced placental vascularization } \\
\text { with embryonic blood vessels }\end{array}$ & 27 \\
\hline
\end{tabular}

transporters GLUT1 and GLUT3 from the apical plasma membrane, which resulted in the inhibition of the mammalian target of rapamycin pathway through AMP kinase. ${ }^{10}$ In contrast to previous gene $\mathrm{KO}$ studies, in which the deletion of $\mathrm{K} 8$ or the combined deletion of K18/K19 and of K8/K19 caused fragility of trophoblast giant cells, followed by extensive hemorrhages, ${ }^{11,12}$ we found that tissue integrity and apical cell polarity of the embryonic epithelia were largely maintained in keratin null embryos. The depletion of keratins rather caused an attachment defect of endodermal and mesodermal tissues in the yolk sac, resulting in decreased hematopoiesis and vasculogenesis through reduced Forkhead box protein F1 signaling and its downstream targets bone morphogenetic protein and P-p38 mitogen-activated protein kinase in the yolk sac mesoderm. ${ }^{9}$

The function of keratins in the placenta has not been fully elucidated. In a subset of K8-deficient embryos, increased sensitivity to tumor necrosis factor-mediated apoptosis was observed in a mouse strain-dependent manner. ${ }^{13,14}$ In contrast, other studies reported trophoblast fragility after the combined deletion of $\mathrm{K} 18 / 19$ or K8/K19. ${ }^{11,12}$ Survival and growth of the embryo critically depend on the placenta. The placenta forms the interface between maternal and fetal circulation, facilitating gas, nutrient, and waste exchange. ${ }^{15}$ It comprises the epithelial trophectoderm cells that on implantation of the embryo into the uterine wall at around E4.5 expand and differentiate. The first embryonic cells to interact with the maternal tissue are the trophoblast giant cells (TGCs) that invade and attach to the uterine wall and induce decidualization by altering specific gene expression among others for vascular remodeling and angiogenesis secreting various hormones such as prolactin-like protein a (Prlpa). ${ }^{16}$
The vascularization of the murine placenta starts at E8.5 with the fusion of the mesodermal allantois to the chorion and the invagination of the fetal blood vessels. This process relies on a highly coordinated cross talk between the epithelial trophoblast and the embryonic endothelium, modulated by transcription factors and signaling receptors on the epithelial ${ }^{17-29}$ as well as on the endothelial side. ${ }^{30-39}$ These factors are essential for the development of the proper vasculature in the placental labyrinth (Tables 1 and 2).

Furthermore, a localized oxygen gradient has been shown to be critical in human decidualization and placentation by influencing vascular remodeling in the decidua and differentiation of trophoblast cells. ${ }^{40}$ Increasing evidence suggests that the same holds true for mice. ${ }^{41}$ Both implantation and ensuing placentation start under hypoxic conditions until the vascular network between maternal and embryonic tissues is properly established and the placenta is flooded with maternal blood. Hypoxia is necessary for normal vascularization. ${ }^{42}$ The hypoxia-inducible factors (HIFs), $\operatorname{HIF} 1 \alpha, \operatorname{HIF} 2 \alpha$, and HIF1 $\beta$ (ARNT) directly promote vascular endothelial growth factor (VEGF) expression, ${ }^{43}$ because their absence in various $\mathrm{KO}$ models showed a reduced vascularization and developmental retardation of the placenta. ${ }^{17,20,24}$ In humans, increased hypoxia leads to preeclampsia, a syndrome causing substantial maternal and fetal mortality in pregnancies. Hallmarks of preeclampsia are reduced trophoblast invasion, reduced vasculature of the placenta, and increased serum levels of soluble fms-related tyrosine kinase 1 (sFlt1). ${ }^{44,45}$ Conversely, untimely elevated oxygen levels in decidual and placental tissues cause regression of placental villi, 
Table 2. Mouse Mutants of Endothelial Cells with Similar Phenotypes

\begin{tabular}{|c|c|c|c|c|}
\hline Gene & Gene product & $\begin{array}{c}\text { Expression pattern in placental } \\
\text { tissue and yolk sac }\end{array}$ & Mutant phenotype & Reference \\
\hline Ang1 & Angiopoietin 1, Tie2 ligand & $\begin{array}{l}\text { Arterial endothelial cells of yolk } \\
\text { sac and placenta }\end{array}$ & $\begin{array}{l}\text { Defects in angiogenic vascular } \\
\text { remodeling in yolk sac and } \\
\text { placenta }\end{array}$ & 30 \\
\hline Ang2 & $\begin{array}{l}\text { Angiopoietin 2, Ang1 } \\
\text { antagonist }\end{array}$ & $\begin{array}{l}\text { Arterial endothelial cells of yolk } \\
\text { sac and placenta }\end{array}$ & $\begin{array}{l}\text { Overexpression leads to defects } \\
\text { in angiogenic vascular } \\
\text { remodeling in yolk sac and } \\
\text { placenta }\end{array}$ & 31 \\
\hline DII4 & Delta-like ligand & $\begin{array}{l}\text { Arterial endothelial cells of yolk } \\
\text { sac and placenta }\end{array}$ & Arterial atrophy & 33,35 \\
\hline Flk1 & $\begin{array}{l}\text { Vascular endothelia growth } \\
\text { factor receptor } 2\end{array}$ & Yolk sac mesoderm, labyrinth & $\begin{array}{l}\text { Lack of endothelia cells and } \\
\text { hematopoietic system }\end{array}$ & 32,37 \\
\hline Flt1 & $\begin{array}{l}\text { Vascular endothelia growth } \\
\text { factor receptor } 1\end{array}$ & $\begin{array}{l}\text { Yolk sac mesoderm, } \\
\text { spongiotrophoblast }\end{array}$ & $\begin{array}{l}\text { Disorganized embryonic } \\
\text { vasculature }\end{array}$ & 32,34 \\
\hline Notch1 & $\begin{array}{l}\text { Single-pass transmembrane } \\
\text { receptor }\end{array}$ & $\begin{array}{l}\text { Arterial endothelial cells of yolk } \\
\text { sac and placenta }\end{array}$ & $\begin{array}{l}\text { Defects in angiogenic vascular } \\
\text { remodeling in yolk sac and } \\
\text { placenta }\end{array}$ & 36 \\
\hline Tie2/Tek & Receptor tyrosine kinase & $\begin{array}{l}\text { Arterial endothelial cells of yolk } \\
\text { sac and placenta }\end{array}$ & $\begin{array}{l}\text { Reduced number of endothelia } \\
\text { cell, disorganized embryonic } \\
\text { vasculature }\end{array}$ & 38,39 \\
\hline
\end{tabular}

spongiotrophoblast tissue, and intrauterine growth restriction through premature maternal blood flow to the placenta. ${ }^{46,47}$ The underlying gene defects, however, are not well known, and molecular defects causing these alterations still have to be identified.

Here, we demonstrate a crucial role of keratins for vascular remodeling in the decidua and in the labyrinth through an altered localization of TGCs. Subsequently, TGC mislocalization altered proper hormone secretion and induced hypervascularization and increased oxygen levels in the decidua. Further, we find that keratins control GLUT1 localization also in extraembryonic tissues. Our findings show that keratins control embryo development in an isotype- and context-dependent manner and suggest that keratin mutations may contribute to early pregnancy losses in conditions of maternal hyperoxia.

\section{Materials and Methods}

\section{Animals}

All experimental animal procedures were conducted according to approved experimental animal licenses issued by the responsible animal welfare authority (Landesamt für Natur, Umwelt und Verbraucherschutz NRW). KtylI ${ }^{-1-}$ mice were bred from heterozygous animals, generated and genotyped as described previously, ${ }^{10}$ and maintained in a C57BL/6 background.

\section{Transgenic Mice, Immunofluorescence Microscopy, and in Situ Hybridization}

Mouse concepti at different gestational ages were prepared. For light microscopy and immunofluorescence analysis, tissues were snap-frozen in isopentane precooled at $-80^{\circ} \mathrm{C}$ and stored at the same temperature. Immunofluorescence analysis was performed as follows: Frozen sections (8 to $12 \mu \mathrm{m}$ thick) were fixed in acetone at $-20^{\circ} \mathrm{C}$ for 10 minutes and dried for a few hours before further processing. All antibodies were diluted in Trisbuffered saline containing $1 \%$ bovine serum albumin and $5 \%$ normal goat serum, Alexa 488/594-conjugated secondary antibodies (Dianova, Hamburg, Germany) were used 1:800 diluted. Slides were mounted in ProLong Gold antifade reagent (Invitrogen, Carlsbad, CA). ${ }^{48}$ GLUT1 (Millipore Corporation, Billerica, MA), K8/K18 (Progen Biotecknik GmbH, Heidelberg, Germany), and K19 (Magin Lab) staining were performed as described before. $^{10}$

For routine histology, tissues were fixed overnight at $4^{\circ} \mathrm{C}$ in $4 \%$ formalin, sequentially incubated at $4^{\circ} \mathrm{C}$ overnight in $15 \%$ and $30 \%$ sucrose, embedded in paraffin, and sectioned $(5 \mu \mathrm{m})$. Sections were placed on superfrost-plus slides (Menzel-Gläser, Braunschweig, Germany) and dried. After deparaffination, sections were either stained with H\&E, ${ }^{48}$ periodic acid-Schiff, ${ }^{49}$ Dolichos bilforus agglutinin lectin (Vector Laboratories, Burlingame, CA), diluted 1:100 for 1 hour in Tris-buffered saline, $1 \%$ bovine serum albumin, $5 \%$ normal goat serum or used for immunohistochemistry. For CD31 (SZ31; Dianova), CD34 (MEC 14.7; Hycult Biotech, Uden, The Netherlands), Hif1 $\alpha$ (Novus Biologicals Inc., Littleton, CO), VEGF (VG-1), and placental growth factor (PIGF; Abcam, Cambridge, MA) staining on paraffin sections, antigens were retrieved with citrate buffer $(18 \mathrm{mmol} / \mathrm{L}$ citric acid, $82 \mathrm{mmol} / \mathrm{L}$ sodium citrate, $\mathrm{pH} 6.0$ ), and the antibodies were diluted in Tris-buffered saline containing $1 \%$ bovine serum albumin and 5\% normal goat serum $1: 20,1: 50,1: 100,1: 50$, and 1:20, respectively. For cleaved caspase 3 (Cell Signaling Technologies, Danvers, MA) staining of paraffin sections, antigens were retrieved with EDTA buffer (1 mmol/L EDTA, $\mathrm{pH}$ 8.0), peroxidases blocked 10 minutes in $3 \%$ hydrogen peroxide, and the antibodies were diluted in Tris-buffered saline containing $1 \%$ bovine serum albumin and $5 \%$ normal goat serum 1:200. The histochemistry was performed with Super Sensitive Link Label IHC Detection system 
(BioGenex, San Ramon, CA) and visualized with diaminobenzidine (DAB; Dako, Giostrup, Denmark).

For mRNA in situ hybridization experiments, concepti were processed as above and sectioned. Sections (10 $\mu \mathrm{m})$ were hybridized with digoxigenin-labeled riboprobes for the various placental lineage markers, ${ }^{50,51} \mathrm{~K} 8$, placental lactogen 1 (Pl1), ${ }^{52}$ trophoblast specific protein alpha (Tpbpa), ${ }^{53} \mathrm{Prlpa}^{,{ }^{5}}$ glial cells missing (Gcm1), ${ }^{55}$ and SyncytinA. ${ }^{50}$ The probes were detected with alkaline phosphatase-conjugated anti-digoxigenin antibody and 5-bromo-4-chloro-3-indolyl phosphate/nitro blue tetrazolium (BCIP/NBT) as chromogenic substrate. ${ }^{50}$

\section{Immunofluorescence Microscopy and Data Processing}

Images of stained paraffin sections were acquired with the use of a fluorescence microscope (Axioplan 2; Carl Zeiss Inc., Thornwood, NY) with a Plan-Neofluar $10 \times$
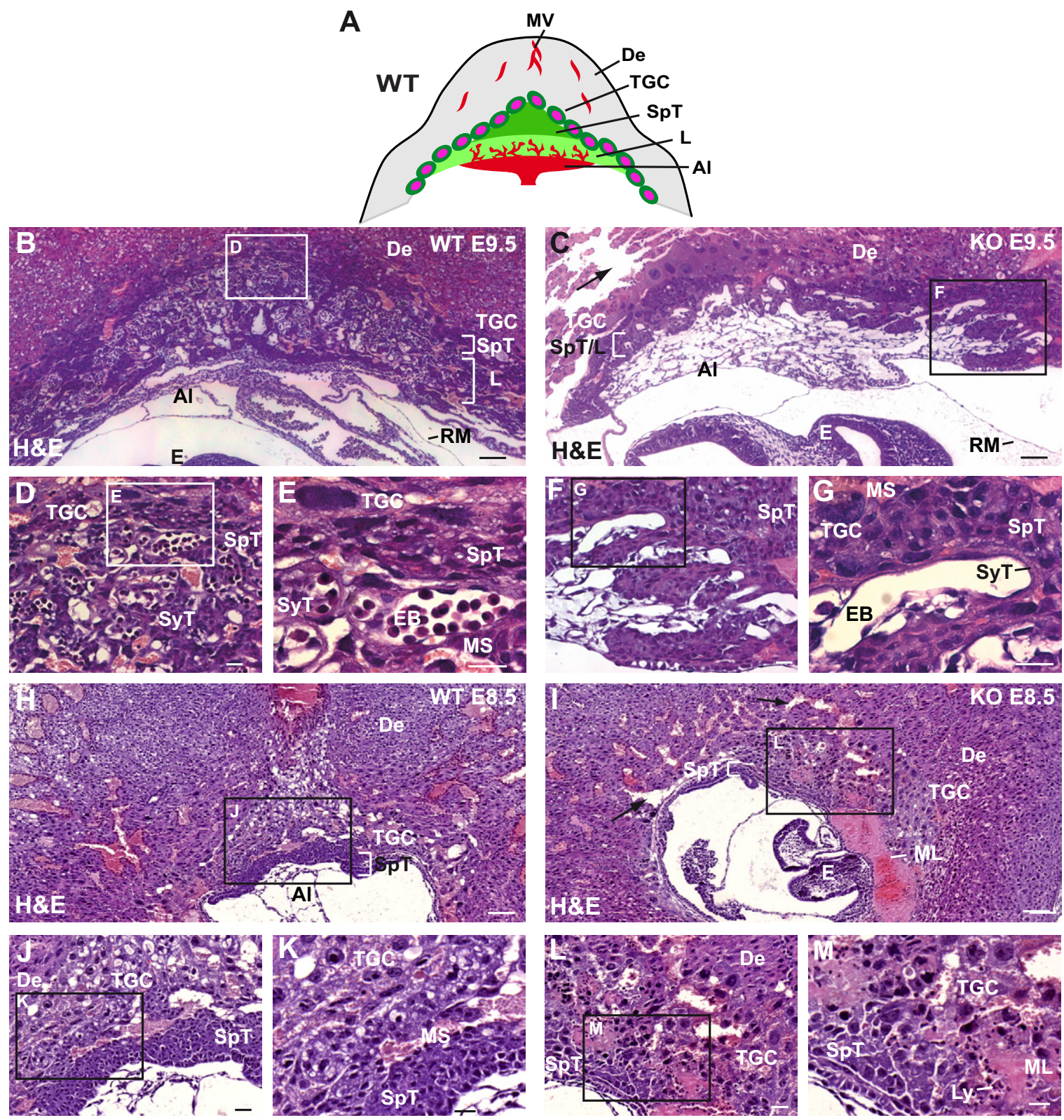

Figure 1. Severe reduction of labyrinth, spongiotrophoblast, and vascular defects were seen in the placenta of keratin-depleted embryos. A: Diagram of placental architecture. B-M: Semithin sections through WT $(\mathbf{B}, \mathbf{D}, \mathbf{E}, \mathbf{H}, \mathbf{J}$, and $\mathbf{K})$ and mutant $(\mathbf{C}, \mathbf{F}, \mathbf{G}, \mathbf{I}, \mathbf{L}$, and $\mathbf{M})$ embryos were stained with H\&E. Note size difference of the labyrinth in keratin KO placenta (C) compared with WT placental control (B), starting at E8.5 in KO embryos (I). Increased vasculature in the decidua, surrounding the mutant embryo begins at E8.5 (arrow in $\mathbf{C}$ and $\mathbf{I}$ ), resulting in maternal leakage of blood and lymphocytes into embryonic tissues (I and $\mathbf{M}$ ). In higher magnifications, marked in the overview of E9.5 WT (D, E, magnified from B) and KO placenta (F, G, magnified from $\mathbf{C})$, WT embryonic blood vessels are packed with embryonic erythrocytes compared with sparsely filled KO blood vessels. Further magnification of WT (E, magnified from $\mathbf{D})$ and KO placentas $(\mathbf{G}$, magnified from F) show that WT embryonic blood vessels are in close proximity to maternal blood sinuses in contrast to KtyII ${ }^{-1}$ labyrinth, which contains few maternal blood sinuses. MV, maternal blood vessels; De, decidua; TGC, trophoblast giant cells; SpT, spongiotrophoblast; L labyrinth; ML, maternal blood lacuna; Ly, lymphocytes; Al, allantois; RM, Reichert's membrane; SyT, syncytiotrophoblast; EB, embryonic blood; MS, maternal blood sinus. Scale bars: $33 \mu \mathrm{m}(\mathbf{B}) ; 50 \mu \mathrm{m}(\mathbf{C}, \mathbf{H}$, and I); $10 \mu \mathrm{m}(\mathbf{D}-\mathbf{G}$ and $\mathbf{J}-\mathbf{M})$. 
0.30 NA objective or a Plan-Apochromat $63 \times 1.4$ NA oil immersion objective at room temperature using an AxioCam MR camera (Carl Zeiss Inc.). Image analysis and processing were performed with AxioVision 4.6 (Carl Zeiss Inc.) and Photoshop 6.0 (Adobe Systems, Mountain View, CA) software. Lookup table (brightness and gamma) was adjusted with Photoshop.

\section{Western Blotting}

Western blotting was performed as described..$^{10}$ In short, total proteins were extracted in SDS-polyacrylamide gel electrophoresis sample buffer under repeated heating $\left(95^{\circ} \mathrm{C}\right)$ and sonication cycles. Total protein concentration was determined by the Bio-Rad protein quantification kit, and equal amounts of protein were loaded. Separation of total protein extracts was carried out by standard procedures ( $8 \%$ and $10 \%$ SDS-polyacrylamide gel electrophoresis). The immunostaining was performed as described earlier. ${ }^{10}$ Primary antibodies were diluted as follows: Hif $1 \alpha$ at 1:500 (Novus Biologicals), VEGF at 1:500 (VG-1; Abcam), and tubulin at 1:5000 (B 5-1-2, Sigma-Aldrich, St. Louis, MO). Secondary antibodies (Dianova) were diluted at 1:20,000 and detected with Super Signal (Thermo Fisher Scientific Inc., Rockford, IL). ${ }^{48}$

\section{Hypoxia Assay and sFlt1 ELISA}

Mice were injected with $60 \mathrm{mg} / \mathrm{kg}$ pimonidazole intraperitoneally (Hypoxyprobe-1; Hypoxyprobe, Inc., Burlington, MA) 2.5 hours before they were sacrificed. E9.5 mouse embryos were dissected and prepared for histology as described above. Immunohistochemical analysis with Hypoxyprobe-1 was performed as described by the manufacturer (Hypoxyprobe, Inc.) with the use of the hybridoma 4.3.11.3 (1:25). For the sFLT1 enzyme-linked immunosorbent assay (ELISA), nonpregnant and pregnant mice (E9.5) were sacrificed by cervical dislocation, and blood was extracted from the heart. Serum was collected, and the ELISA for sFLT1 was performed according to manufacturer's protocol (R\&D Systems, Minneapolis, $\mathrm{MN})$.

\section{Results}

\section{Keratins Are Necessary for Placental Labyrinth and Decidual Development but Do Not Determine Cell Fate}

To investigate to which extent formation of placental epithelia depends on keratins, we first analyzed placenta morphology in histologic sections of various developmental stages of keratin-deficient $\left(\mathrm{Ktyll}^{-/-}\right)$and wild-type (WT) embryos with their surrounding placental and decidual tissues (Figure $1 \mathrm{~A}$, model). Until E8.5, the placenta of keratin null embryos developed normally and underwent a typical chorioallantoic attachment (Figure 1, H-M). By E9.5, however, a drastic difference in size became apparent (Figure 1, B and C). Mutant placentas were smaller and enriched in cells (Figure 1, C, F, and G) compared with WT controls (Figure
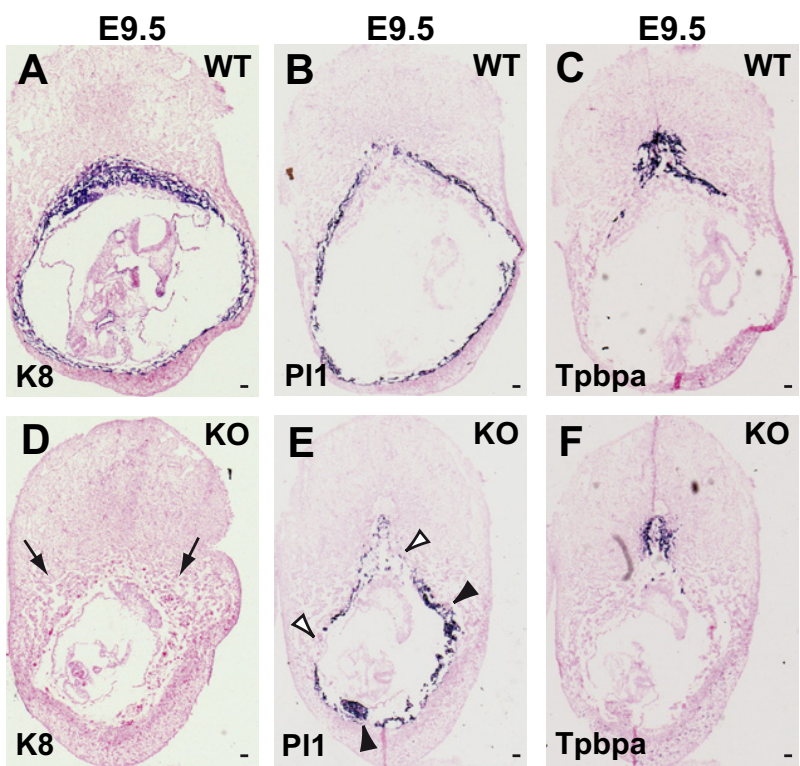

E8.5
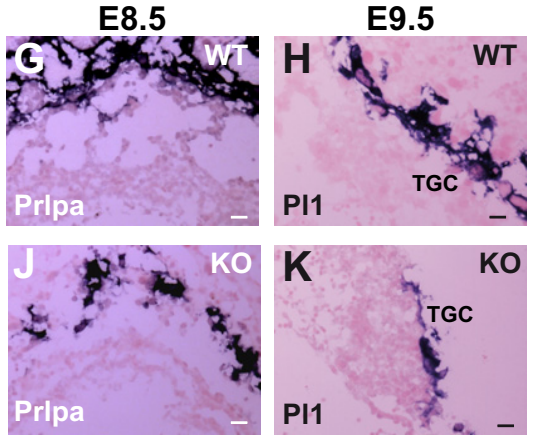

E9.5
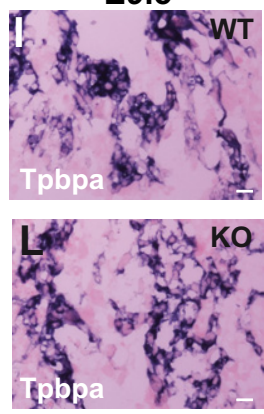

Figure 2. Spatial mislocalization of TGCs, but no differentiation defects in $\mathrm{KtyII}^{-/-}$embryos. In situ hybridizations of labyrinth trophoblast markers K8, Pl1, Tpbpa, and Prlpa. A and D: Keratin 8 hybridization differentiates between WT (A) and KO (D) embryos. Note increased vasculature in the KO decidua (arrow in D). Pl1, a marker for TGCs, shows no differentiation defects of TGCs in $\mathrm{KtyII}^{-/-}$embryos (E) compared with control TGC (B); however, Pl1 staining shows a discontinuous layer of TGCs in KO embryos, with areas of accumulation (black arrowheads) and areas of underrepresented TGCs (white arrowheads). In situ hybridizations of the spongiotrophoblast marker Tpbpa display no difference in KO (F) compared with WT (C) placentas. H-L: Higher magnifications of above-mentioned markers. G and $\mathbf{J}$ : Expression for Prlpa, a hormone secreted by the TGCs, is already at E8.5 notably reduced in the KO TGC (J) compared with WT TGC (G). P11 hybridization in KO placenta demarcates an area with reduced TGCs (K), compared with a continuous signal in WT TGC layers (H). At higher magnification no difference between WT (I) and mutant (L) placentas in Tpbpa signal was notable. Scale bars: $100 \mu \mathrm{m}(\mathbf{A}-\mathbf{F}) ; 10 \mu \mathrm{m}(\mathbf{G}-\mathbf{L})$

$1, B, D$, and $E$ ) and showed significantly impaired vasculature. H\&E staining of these placentas showed that fetal blood vessels were present, but that they were fewer in number and appeared dilated (Figure 1, F and G) compared with WT placentas (Figure 1, D and E). In addition, embryonic vessels of the KO placenta showed a defect in embryonic hematopoiesis, containing less embryonic erythrocytes in comparison to WT placentas. Ktyll ${ }^{-1-}$ embryos also had defects in the vascularization of the decidua, characterized by a discontinuous, decomposed loose structure of the peri-vitelline network (Figure 1, C and I; Figure 2D; Figure 3B; and Figure 4, C and D), the aggregation of maternal blood lacunae in between the trophoblast layers of the TGCs and the spongiotropho- 

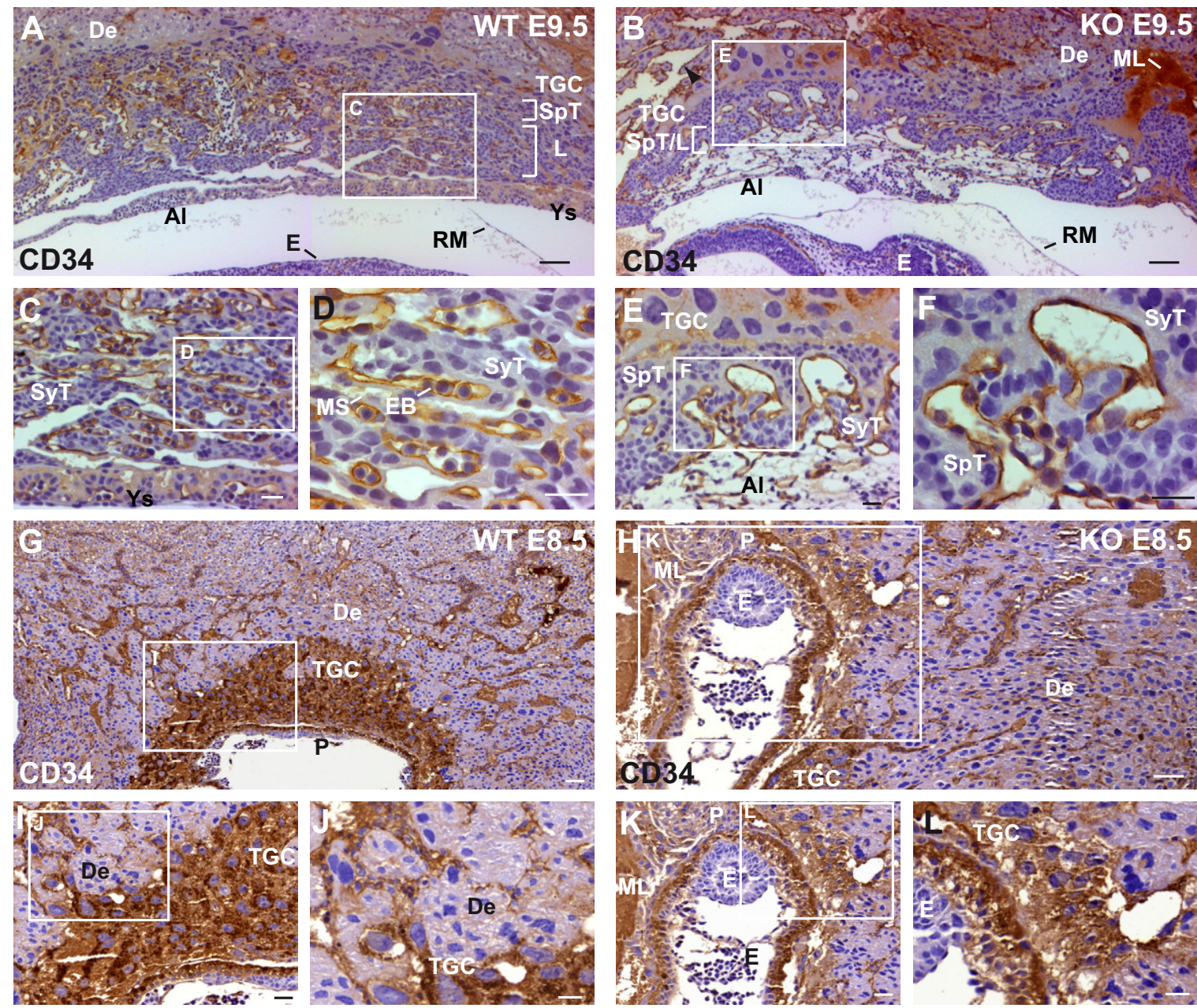

Figure 3. Keratin $\mathrm{KtyII}^{-/-}$embryos show a dysfunctional vasculature in the placental labyrinth. Immunohistochemical staining with anti-CD34 antibodies in WT $(\mathbf{A}, \mathbf{C}, \mathbf{D}, \mathbf{G}, \mathbf{I}$, and $\mathbf{J})$ and $\mathrm{KO}(\mathbf{B}, \mathbf{E}, \mathbf{F}, \mathbf{H}, \mathbf{K}$, and $\mathbf{L})$ placentas. The WT labyrinth shows extensive staining with CD34 antibodies (A), displaying an extensive vasculature network. In contrast, embryonic vessels fail to invade the labyrinth properly. Further note accumulation of TGCs (B and $\mathbf{E}$ ) adjacent to the extensive maternal vasculature (black arrowhead) and the presence of maternal blood lacunae in the KO placenta (B). In the higher magnifications (C-F), embryonic W' controls displayed small vessels filled with nucleated embryonic erythrocytes, in close vicinity to maternal blood sinuses (D, inlay of $\mathbf{C}$ ) In contrast, KO vessels seemed dilated with a thickened syncytiotrophoblast layer, containing few nucleated embryonic erythrocytes (F, magnified from E). Vascular defects already became apparent at E8.5, including maternal leakage into the KO embryo (H, K and $\mathbf{L}$, magnified from $\mathbf{K}$ ) compared with the WT situation ( $\mathbf{G}$, I and $\mathbf{J}$, magnified from I). De, decidua; TGC, trophoblast giant cells; SpT, spongiotrophoblast; L labyrinth; ML, maternal blood lacuna; Al, allantois; RM, Reichert's membrane; Ys, yolk sac; E, embryo; SyT, syncytiotrophoblast; EB, embryonic blood; MS, maternal blood sinus. Scale bars: $50 \mu \mathrm{m}(\mathbf{A}$ and $\mathbf{B}) ; 10 \mu \mathrm{m}(\mathbf{C}-\mathbf{F})$.

blast with infiltrating lymphocytes (Figure 1, I and $\mathrm{M}$; Figure 3, B and $\mathrm{H}$; Figure 4D; and Figure $5 \mathrm{G}$ ) which became apparent already at E8.5. In contrast to WT embryo TGCs showed an irregular distribution. They were accumulated in some regions and underrepresented in others (Figure 1, C and I; Figure 4C; and Figure 5G). This was accompanied by the leakage and accumulation of maternal blood (Figure 1, I and M; Figure 3, B and $\mathrm{H}$, Figure $4 \mathrm{D}$; and Figure $5 \mathrm{G}$ ) in $>90 \%$ of the $\mathrm{KO}$ embryos.

To examine whether the phenotype resulted from increased apoptosis, histochemical analysis for cleaved caspase 3 was performed. This clearly showed absence of trophoblast cell lysis and no increase in trophoblast cell apoptosis. In agreement with published data, ${ }^{10}$ the embryo proper displayed an increased number of apoptotic cells. Previously, trophoblast fragility was reported after the deletion of $\mathrm{K} 18 / 19$ or $\mathrm{K} 8 / \mathrm{K} 19 .{ }^{11,12}$ In $\mathrm{Ktyll}^{-/-}$, serial sections indicated a slight decrease in TGC numbers but failed to detect any evidence for trophoblast cytolysis (see Supplemental Figure S1 at http://ajp.amjpathol.org). This indicated that aggregated keratins may contribute to cell lysis in the former setting. To further analyze the misdistribution of TGCs, epithelial differentiation was investigated with the use of several lineage markers for the major trophoblast cell types (Figure 2). In situ hybridization showed that the outermost trophoblast layer, the giant cells, expressed $\mathrm{Pl} 1$ (Figure 2, B, E, H, and K), and the spongiotrophoblast cells were positive for Tpbpa (also known as 4311; Figure 2, C, F, I, and L). ${ }^{52,53}$ This showed that lack of keratins did not alter epithelial differentiation in the placenta per se. However, we noted an altered distribution of the TGC marker PI1, indicating a mislocalization of TGCs (Figure 2E arrowheads). Moreover, the mRNA for the secreted Prlpa, a member of the prolactin family, was strongly reduced in $\mathrm{Ktyll}^{-1-} \mathrm{TGCs}$ compared with WT cells (Figure 2, G and J). Prlpa is produced by trophoblast cells and specifically interacts with uterine natural killer (uNK) cells. ${ }^{56,57}$ During preg- 


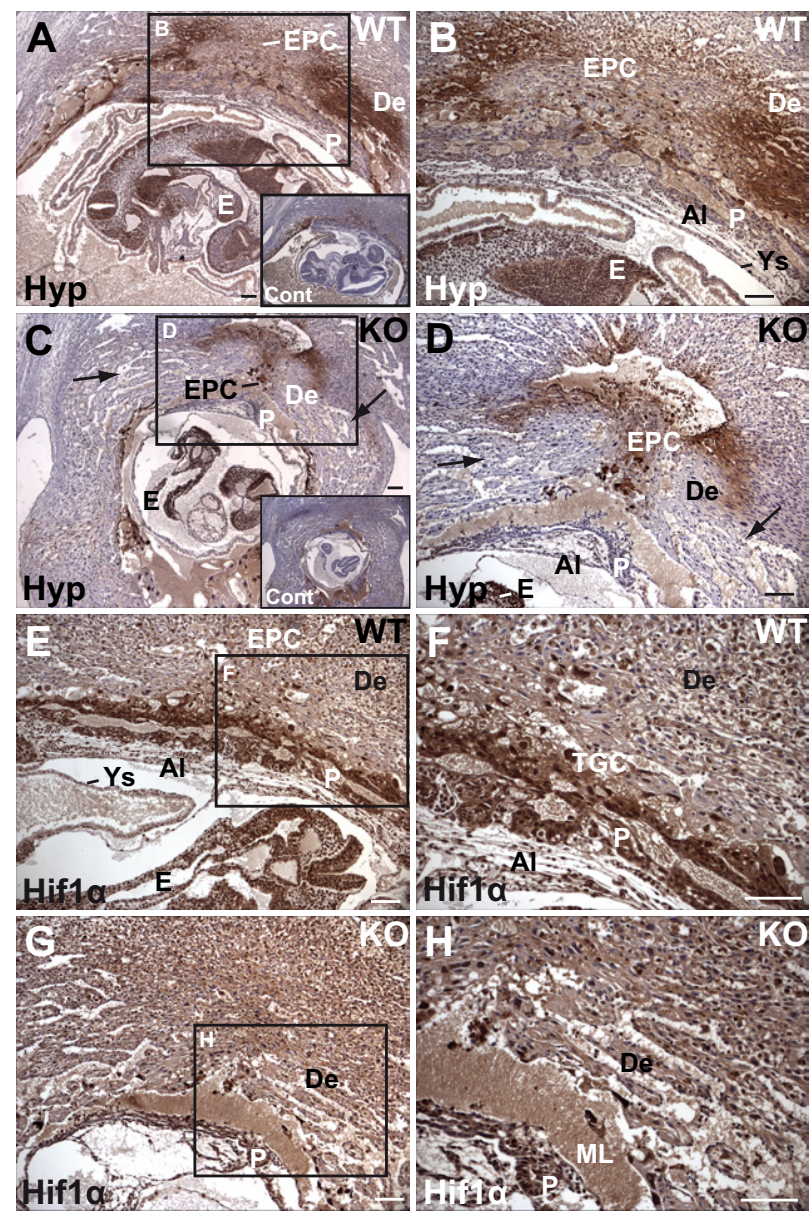

Figure 4. Hyperoxia in decidual tissue surrounding keratin KO embryos leads to reduced induction of the downstream signal Hif $1 \alpha$. Localization of hypoxic regions in implantation sites of E9.5 WT (A) and KO (C) embryos using Hypoxyprobe-1-specific antibody. Strong hypoxic staining is present in WT decidual tissue enclosing the EPC, more explicit at higher magnification ( $\mathbf{B}$, magnified from $\mathbf{A}$ ) in contrast to mutant decidua, where the hypoxic area around the EPC is reduced because of an increased vasculature of the maternal decidua, marked by black arrows $(\mathbf{D}$, magnified from $\mathbf{C})$. Controls in $\mathrm{A}$ and $\mathrm{C}$ are negative controls without antibody staining. Hif $1 \alpha$ expression manifested predominantly in the placenta of WT $(\mathbf{F}$, magnified from $\mathbf{E})$ and to some extent in KO placentas ( $\mathbf{H}$, magnified from $\mathbf{G})$, but less so in the decidua (E-H). P, placenta; De, decidua; TGC, trophoblast giant cells; E, embryo; Ys, yolk sac; EPC, ectoplacental cone; ML, maternal blood lacuna Hyp, hypoxia. Scale bars: $100 \mu \mathrm{m}(\mathbf{A}-\mathbf{H})$

nancy, uNK cells accumulate around the mesometrial uterine vasculature ${ }^{58,59}$ and stimulate vascular remodeling through the secretion of angiogenic factors ${ }^{60}$ facilitating nutrient flow to the placenta and the fetus. ${ }^{61,62}$ In line with these data, we found an increase in uNK cell numbers in the decidua of $\mathrm{KO}$ embryos (Figure 6E). Visualizing uNK cells with Dolichos bilforus agglutinin lectin and PAS staining ${ }^{63}$ further showed a relocalization of UNK cells to the direct vicinity of the ectoplacental cone (EPC) of keratin $\mathrm{Ktyll}^{-1-}$ trophoblast cells (Figure 6, C and D) in contrast to an even distribution in decidual tissues of WT embryos (Figure 6, A and B). Uterine NK cells were furthermore shown to secrete growth factors such as VEGF and the VEGF-related factor PIGF, adding to the decidual hypervascularization phenotype.

We conclude that the keratin-dependent altered spatial distribution of the TGCs and the compromised secre- tion of hormones ${ }^{10}$ trigger an increase in decidual uNK cell numbers and result in an extension of maternal vasculature. These changes contribute to the embryonic death of $\mathrm{Ktyll}^{-1-}$ embryos.

In situ hybridization on implantation sites of E8.5 and E9.5 embryos with a Gcm1 probe, which demarcates the sites for the initiation of branching morphogenesis along the leading edge of the chorion at the interface with the allantois $^{51}$ and for SyncytinA, a marker for the development of the syncytiotrophoblast, ${ }^{50}$ did not show any alterations in expression levels in $\mathrm{Ktyll}^{-1-}$ embryos (see Supplemental Figure S2 at http://ajp.amjpathol.org).

\section{Vascular Defects in Ktyll ${ }^{-/-}$Placentas}

We recently demonstrated that $\mathrm{Ktyll}^{-1-}$ embryos at E9.5 could be easily discriminated from WT embryos by their pale yolk sacs. The depletion of keratins caused an at-
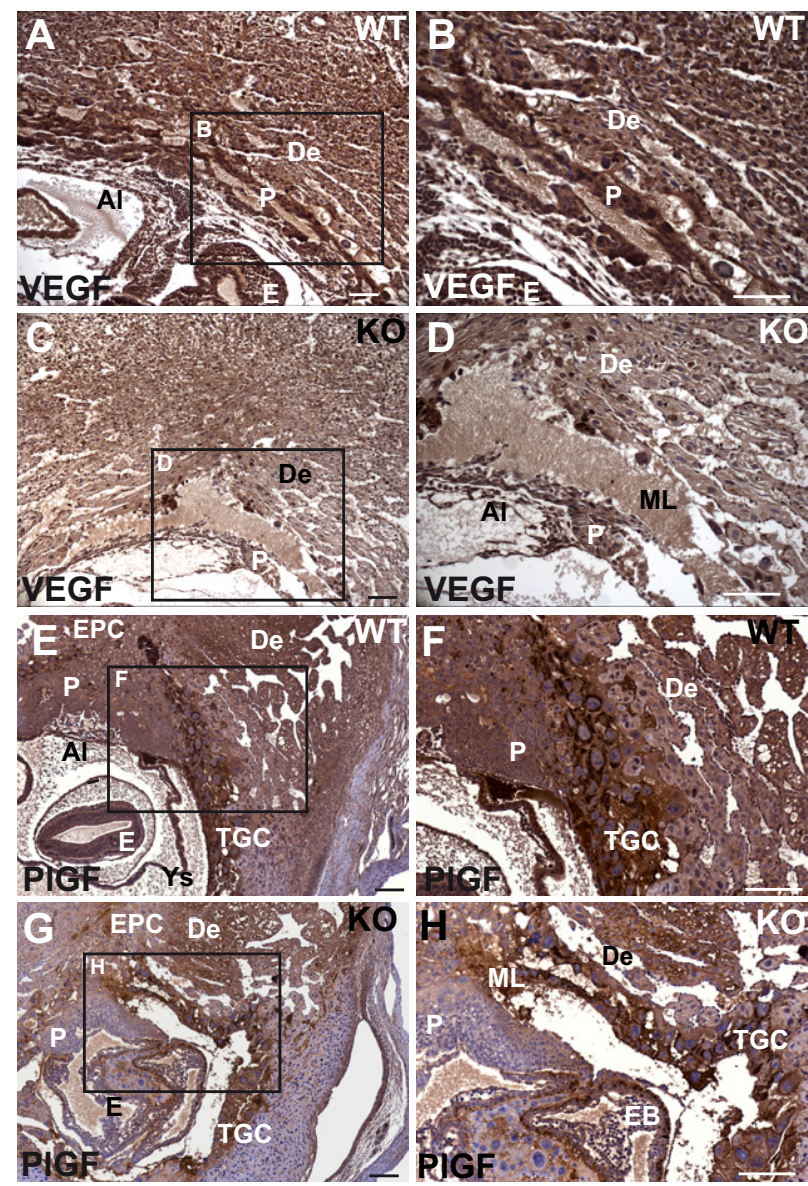

Figure 5. Hyperoxia in decidual tissue surrounding keratin $\mathrm{KO}$ embryos leads to reduced induction of downstream signals VEGF and PlGF. Hypoxia induces the angiogenic factors VEGF (A-D) and PlGF (E-H) through Hif $1 \alpha$, visualized by histochemical antibody staining. VEGF, as soluble factor, is expressed in decidual and placental tissues of WT (A and $\mathbf{B})$ and KO embryos $(\mathbf{C}$ and $\mathbf{D})$. In line with the hyperoxia in the KO, VEGF showed reduced staining in $\mathrm{KtyII}^{-/-}$placenta and decidua (D) compared with the WT (B) Note also the absence of PlGF in the KO placenta $(\mathbf{H})$, whereas decidual expression remained $(\mathbf{G}$ and $\mathbf{H})$. WT tissues showed even distribution of PlGF through placental and decidual tissues (E and F). P, placenta; De, decidua; TGC, trophoblast giant cells; E, embryo; EB, embryonic blood; EPC ectoplacental cone; ML, maternal blood lacuna; Al, allantois. Scale bars: 100 $\mu \mathrm{m}(\mathbf{A}-\mathbf{H})$ 

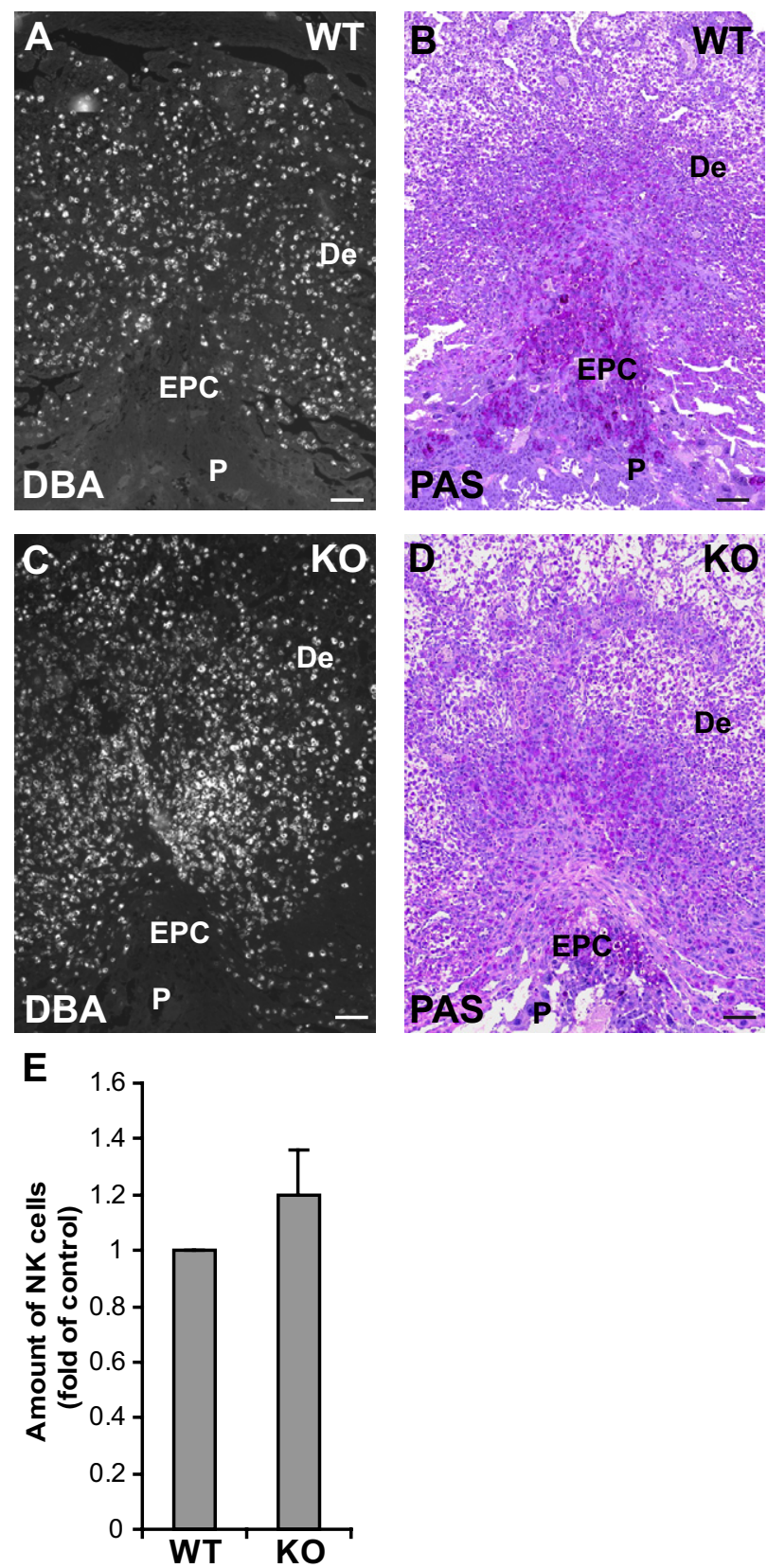

Figure 6. Increased numbers of uNK cells concentrated in the direct vicinity of the KO placenta. uNK cells are visualized with Dolichos bilforus agglutinin lectin (A and $\mathbf{C}$ ) and PAS (B and $\mathbf{D})$ staining on semithin sections. Increased amounts of uNK cells (E) were localized closely along the embryonic trophoblast in the KO placenta (C and D), whereas the WT uNK cells are distributed evenly through the maternal decidua and sparsely around the WT trophoblast cells (A and $\mathbf{B}$ )

tachment defect of endodermal and mesodermal tissues in the yolk sac, resulting in decreased hematopoiesis and vasculogenesis through reduced Forkhead box protein F1 signaling and its downstream targets bone morphogenetic protein and P-p38 mitogen-activated protein kinase in the mesoderm. ${ }^{9}$

The distribution of fetal capillaries in the labyrinth was investigated by immunohistochemistry with the use of antibodies that recognize CD34 (Figure 3) and CD31/ platelet endothelial cell adhesion molecule 1 (see Sup- plemental Figure S3 at http://ajp.amjpathol.org), adhesion molecules expressed on the surface of vascular endothelial cells. ${ }^{64,65}$ In the WT placenta of E9.5 embryos the fetal vessels were evenly distributed throughout the placental labyrinth, always in close contact to maternal blood sinuses to enable the fetal-maternal exchange of gas and nutrients (Figure 3, A, C, and D; also see Supplemental Figure S3 at http://ajp.amjpathol.org). However, in the $\mathrm{Ktyll}^{-I-}$ placenta, fetal blood vessels mostly innervated the chorioallantoic plate and did not show extensive branching into the labyrinth trophoblast as the WT vessels did. They were fewer, appeared dilated, and contained less embryonic blood, and, in addition, very few maternal blood sinuses were identified near the embryonic vessels (Figure 3, B, E, and F; also see Supplemental Figure S3 at http://ajp.amjpathol.org).
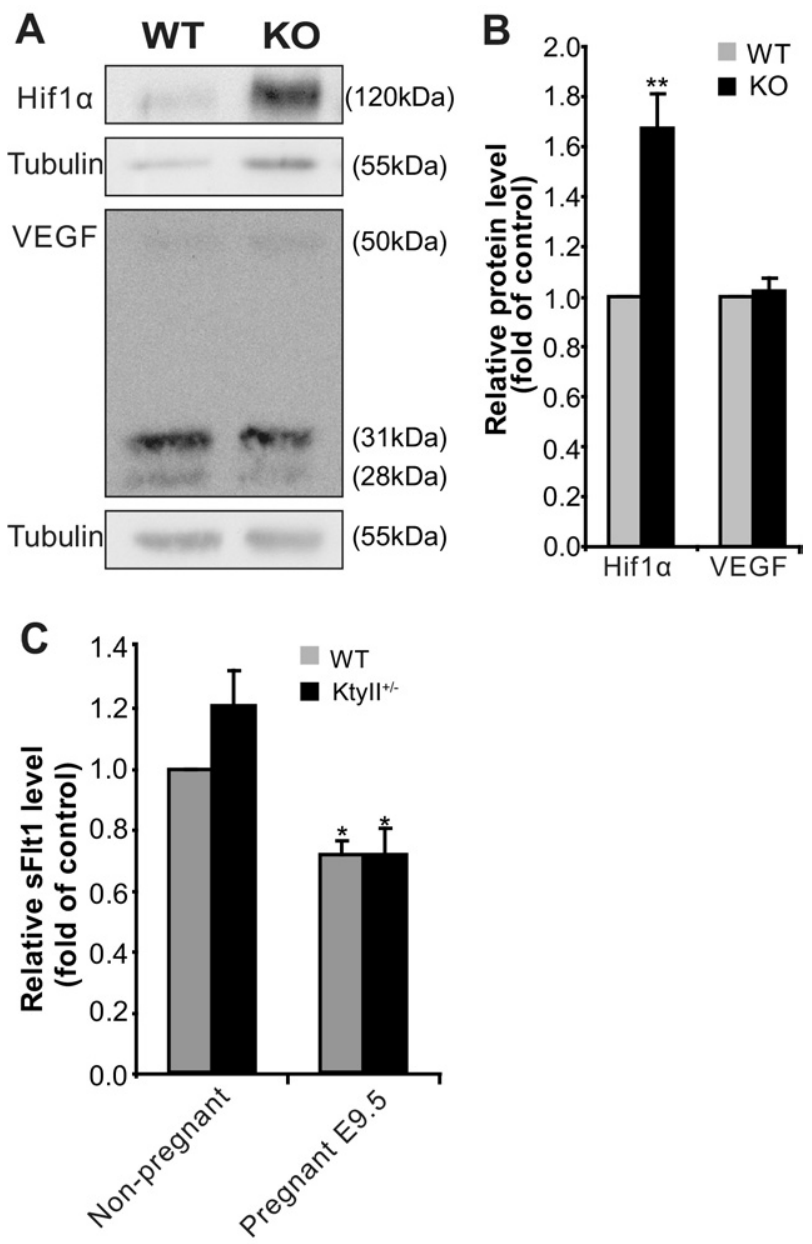

Figure 7. Increased hypoxia inducible factor in the embryo proper of KtyII $^{-1-}$ embryos. A and B: Western blotting of total lysates of E9.5 embryo proper and yolk sac were analyzed against Hif $1 \alpha$ and VEGF in both genotypes. Total protein levels of Hif $1 \alpha$ and VEGF were quantified by densitometry and normalized to tubulin $(n=3 ; \mathbf{B})$, showing a drastic increase of Hif $1 \alpha$ expression in $\mathrm{KtyII}^{-/-}$embryos. VEGF levels remained unaltered. Results are shown as means and SEM; ${ }^{*} P<0.05$ compared with WT controls (two-tailed $t$-test). C: sFLT1 levels in maternal blood serum of untreated versus pregnant WT and $\mathrm{KtyII}^{+/-}$mice determined by ELISA were not increased in pregnant $\mathrm{KtyII}^{+/-}$mice, ruling out preeclampsia as a possible cause for the prenatal death of KO embryos. Nonpregnant wild-type, $n=8$; nonpregnant KtyII ${ }^{+/-}$, $n=13$; day E9.5 pregnant wild-type mice, $n=9$; day E9.5 pregnant $\mathrm{KtyII}^{+/-}, n=8$. Results are shown as means and SEM; ${ }^{* *} P<0.05$ compared with nonpregnant WT controls (two-tailed $t$-test). 

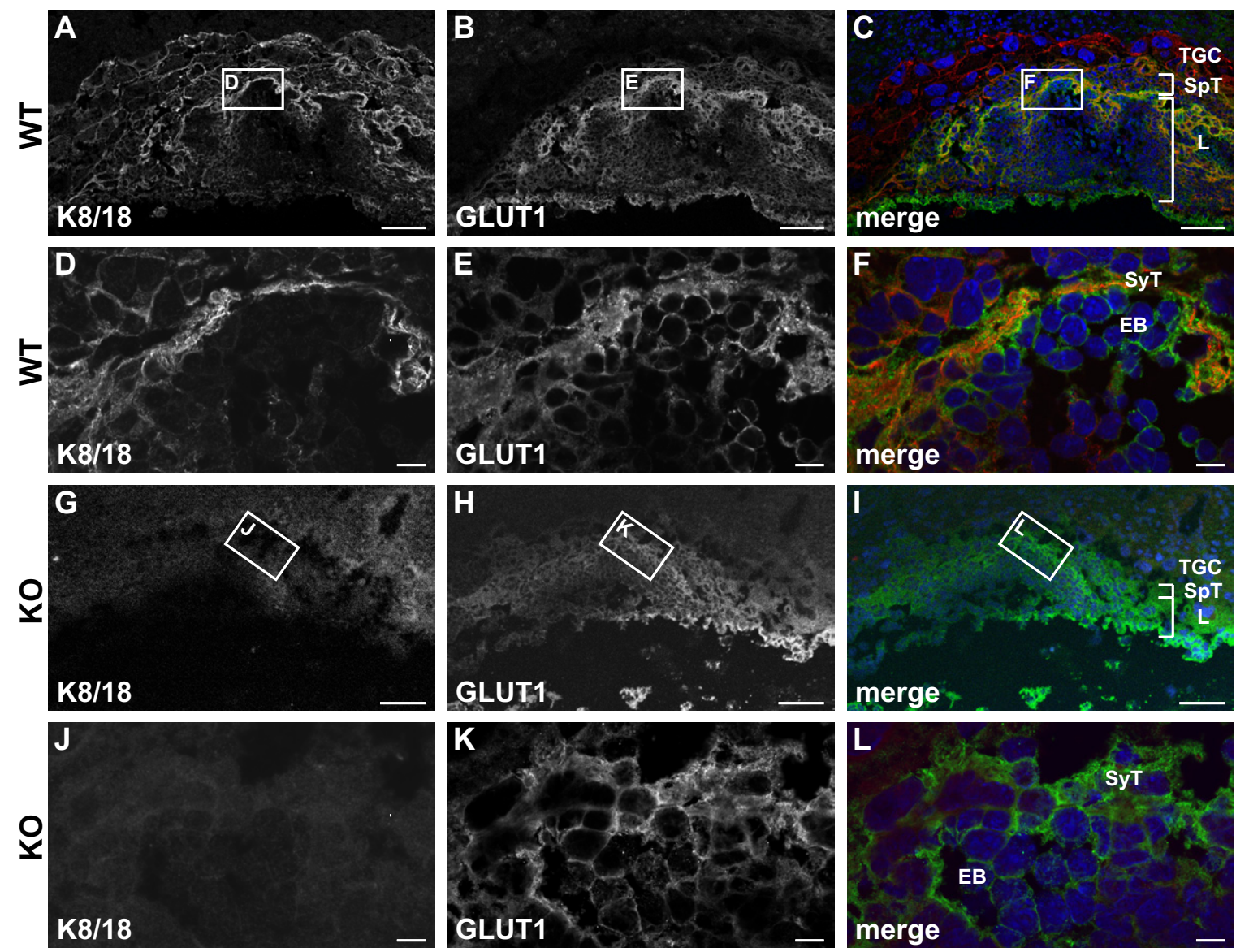

Figure 8. Mislocalization of GLUT1 transporters in trophoblast cells of the labyrinth. Comparing immunofluorescence analysis of WT to KO placental staining with K8/K18 (A, D and G, H) and GLUT1 (B, E and $\mathbf{H}, \mathbf{K})$ antibodies shows a prominent location of GLUT1 transporters in WT syncytiotrophoblast cells, which regulate gas and waste exchange, as well as nutrient transport ( $\mathbf{C}$ and $\mathbf{F})$. In contrast, GLUT1 transporters are mislocalized in KO placental tissues (I and $\mathbf{L})$ similar to yolk sac tissues. ${ }^{10}$ TGC, trophoblast giant cells; SpT, spongiotrophoblast; L, labyrinth; SyT, syncytiotrophoblast; EB, embryonic blood. Scale bars: $100 \mu \mathrm{m}(\mathbf{A}-\mathbf{C}$ and $\mathbf{G - I}) ; 10 \mu \mathrm{m}$ (D-F and $\mathbf{J}-\mathbf{L})$.

\section{Ktyll ${ }^{-1-}$ Embryos Develop Decidual Hyperoxia with an Altered Expression of Vasculogenesis- Promoting Factors}

In human embryonic development, vascularization of the placenta depends on oxygen tension in the surrounding decidual tissues. ${ }^{40}$ Recent murine gene knockout studies of HIF proteins indicated that hypoxia is required for vasculogenesis, angiogenesis, and hematopoiesis in the mouse as well. ${ }^{17,20,24,43}$

This prompted us to examine the state of hypoxia in $\mathrm{Ktyll}^{-/-}$embryos (Figure 4, A-D). Surprisingly, hypoxia was reduced in the $\mathrm{KO}$ decidua compared with the WT controls (Figure 4, A and B) because of increased maternal vasculature (Figure 4, C and D). However, Hypoxyprobe-1 detects only a severe decrease in oxygen levels of $\leq 10 \mathrm{mmHg}$ (1.5\% oxygen) and hence would not detect concentrations of oxygen consistent with milder hypoxia. Therefore, we assessed the localization of Hif1 $\alpha$, which is one of the earliest induced proteins in hypoxia, as soon as 8\% oxygen. We found a strong placental staining in the WT placenta of E9.5 embryos and a weaker staining in the hypoxic areas of the decidua, because Hif $1 \alpha$ is no longer responsive under continuous low oxygen levels and its accumulation levels drop $^{66}$ (Figure 4, E and F). Similar to the WT, the implantation side of the $\mathrm{KO}$ also showed an increase of Hif $1 \alpha$ staining in the placental tissues (Figure 4, G and H). However, the level of Hif $1 \alpha$ in the embryo proper seemed to be elevated in the $\mathrm{Ktyll}^{-1-}$ embryo compared with the WT embryos. This was confirmed by Western blot analysis of protein lysates of the embryo proper and the yolk sac (Figure 7, $A$ and B). Recent studies have shown that Hif $1 \alpha$ induces VEGF expression to induce placental vasculogenesis ${ }^{43}$ through a direct binding of the Hif $1 \alpha$ dimer to the VEGF promoter region. ${ }^{67}$ Therefore, we localized and measured VEGF expression in the WT decidua and placenta (Figure 5, $\mathrm{A}$ and $\mathrm{B}$ ) and compared them with the keratin $\mathrm{Ktyll}^{-\prime-}$ specimen (Figure 5, C and D). We found that there was a decrease of Hif $1 \alpha$ and VEGF in KO placental tissues, which is consistent with the poor vascularization of the $\mathrm{KO}$ placenta (Figure 3). In the embryo proper, no differences in VEGF expression levels were observed (Figure 7, A and B).

VEGF and PIGF are expressed simultaneously during mouse development ${ }^{68}$ and target the same receptor Flt1. ${ }^{69}$ We observed a similar distribution of PIGF protein compared with VEGF in WT embryos (Figure 5, E and F). Furthermore, we found that decidual hyperoxia caused no changes in decidual expression levels in $\mathrm{KO}$ embryos 
(Figure 5, $\mathrm{G}$ and $\mathrm{H}$ ) but led to a drastic decrease in placental PIGF levels, corresponding to the observed decrease of placental vasculogenesis (Figure $5 \mathrm{H}$ ).

Hypoxia was also shown to induce the expression of GLUT1 transporters in early embryonic development. ${ }^{41}$ In line, we found a twofold increase in GLUT1 expression in the embryo proper by quantitative PCR (data not shown), corresponding with our previous findings. ${ }^{10}$ Furthermore, GLUT1 transporters were mislocalized to cytosolic compartments in placental tissues (Figure 8) as previously seen in yolk sac tissues. ${ }^{10}$ Moreover, a reduction of glycogen storage in the $\mathrm{KO}$ trophoblast cell lineage was identified in the EPC region of the $\mathrm{KO}$ embryo compared with WT trophoblast cells (Figure 6, B and D). These findings suggest that keratins act through similar mechanisms in embryonic and extraembryonic tissues, affecting the vascularization and the localization of GLUT1 transporters. The subsequent lack of nutrition contributes to metabolic failure in Ktyll ${ }^{-1-}$ embryos.

\section{Ktyll ${ }^{-/-}$Mice Represent a Novel Model for Decidual Hyperoxia}

Hypoxia-induced HIF1 $\alpha$ protein accumulation in placentas is associated with shallow invasion of trophoblasts into the spiral arteries and the uterine wall (see Supplemental Figure S4 at http://ajp.amjpathol.org), probably resulting in vascular remodeling defects and further hypoxia. ${ }^{44}$ In addition, secretion of sFlt1 into the maternal blood stream and proteinuria are phenotypic hallmarks of the severe pregnancy complication, preeclampsia, in humans and mice. ${ }^{45,70}$ Therefore, we measured protein contents in urine of E9.5 pregnant mice (data not shown), as well as sFlt1 levels in nonpregnant versus pregnant WT and $\mathrm{Ktyll}^{+/-}$mice at E9.5. Both assays excluded keratins as a major contributor to preeclampsia, because there neither was an increase in protein levels in urine (data not shown) nor could a difference in sFlt1 levels in WT and mutant mice sera be detected (Figure 7 C).

\section{Discussion}

The results reported here provide the first evidence that keratins coordinate vascular remodeling in the decidua as well as proper vascularization of the labyrinth in placental development. Their loss led to a reduced oxygen uptake and severe hypoxia. Furthermore, absence of keratins led to an extensive mislocalization of TGCs and a decreased signaling of the placental growth hormones Prlpa and PIGF in the extraembryonic trophoblast. In analogy to previously reported vascularization defects and mislocalization of GLUT1 and GLUT3 transporters in yolk sac tissues, ${ }^{9,10}$ we also found altered GLUT1 distribution and vascular defects in the extraembryonic trophoblast. Collectively, our data show that the prenatal death of $\mathrm{Ktyll}^{-/-}$embryos at E9.5 is caused by a sequence of keratin-dependent mechanisms that culminate in metabolic failure in embryonic and extraembryonic tissues. This strongly supports the concept that keratins function in an isotype- and context-dependent manner.
We propose that this defect originates from a mislocalization of trophoblast giant cells, which were identified by $\mathrm{Pl} 1$ in situ hybridization. The primary giant cells are the first embryonic epithelial cells to interact with the maternal tissue and express keratins at high levels; they are responsible for the implantation of the embryo. ${ }^{16} \mathrm{KO}$ embryos developed normally until E8.5 when growth retardation defects emerged; therefore, we propose a defect in secondary giant cells, which arise from the EPC. ${ }^{71}$ This became evident from their failure to form a continuous perivitelline network, because the decidua of $\mathrm{Ktyll}^{-/-}$ embryos displayed hypervascularization compared with the WT placenta, leading to a very loose meshwork with wide maternal blood lacunae already apparent at E8.5. In humans, high oxygen concentration in the periphery of early placentas, induced by a premature onset of maternal placental circulation, is a key factor for early pregnancy loss. In fact, the intervillous space of the developing placenta is separated from the uterine circulation by plugs of trophoblast cells that occlude the tips of the uteroplacental arteries. In complicated pregnancies, invasion of the endometrium by the extravillous trophoblast is severely restricted compared with the normal situation. Plugging of the spiral arteries is therefore less complete and may predispose to the early onset of the maternal circulation. ${ }^{40,47}$ In mice, the TGCs, which function equivalent to human extravillous trophoblasts, invade into the spiral decidual arteries and remodel the maternal blood vessels $^{71,72}$ (see Supplemental Figure S3 at $h$ ttp://ajp. amjpathol.org). The mislocalization of the TGCs could account for a defective plugging of maternal vessels caused by keratin deletion, because keratin-depleted cells were shown to exhibit severe migration and attachment defects. ${ }^{73}$

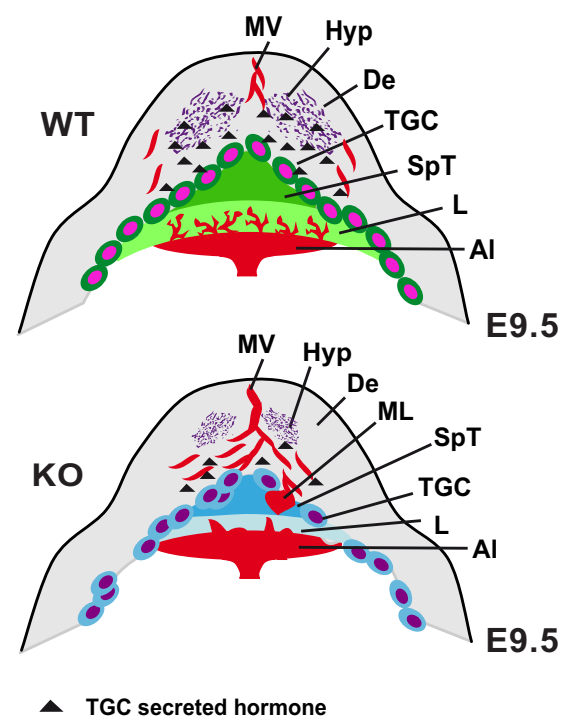

Figure 9. Model for decidual hyperoxia caused by keratin deficiency of the TGCs. TGCs, on the one hand, mislocalize and, on the other, fail to secrete appropriate levels of hormones needed for proper decidualisation. This results in a lower degree of vascularization of the placental labyrinth (keratin positive cells in green and keratin $\mathrm{KtyII}^{-/-}$cells in blue). MV, maternal blood vessels; De, decidua; TGC, trophoblast giant cells; SpT, spongiotrophoblast; L labyrinth; ML, maternal blood lacuna; Al, allantois; Hyp, hypoxia. 
In addition, TGCs are required for initiating decidualization and regulate its development by the secretion of paracrine hormones, such as proliferin and proliferinrelated protein, which have a direct influence on promoting and inhibiting decidual vasculature, respectively. ${ }^{74}$ In this fashion they stimulate angiogenic signals in the decidua-like angiopoietin 1 and 2 and secrete hormones that suppress the immune system of the mother. ${ }^{16}$ An involvement of keratins in the secretion of hormones is in line with their reported function in vesicular trafficking and in receptor and transporter localization at the plasma membrane. ${ }^{10,75}$ One of these hormones is Prlpa, expressed in secondary TGCs, ${ }^{76}$ which suppresses the maternal uNK cells. Here, we demonstrated a reduced number of TGCs, starting as early as E8.5 in $\mathrm{Ktyll}^{-/-}$ embryos and an increased migration of UNK toward the Ktyll ${ }^{-1-}$ placenta. ${ }^{77}$

Hypoxia is a prerequisite for embryonic implantation and development in mammals ${ }^{40,41}$ and is necessary for a normal development of the vasculature. ${ }^{42}$ The increased vascularization of the mutant decidua led to an increase in oxygen level of the placenta, and, in strong support, we detected hyperoxia. Furthermore, we found a drastic reduction in Hif $1 \alpha$ in the $\mathrm{Ktyll}^{-1-}$ decidua and placenta compared with WT. HIFs form heterodimers of Hif $1 \beta$ (ARNT) and Hif $1 \alpha$ or Hif $2 \alpha$. Knocking out any of these 3 proteins, leads to a small labyrinth due to drastically impaired vasculogenesis of the placenta, similar to the phenotype we reported in our $\mathrm{KO}$ embryos. ${ }^{17,20,24,43} \mathrm{As}$ a consequence, reduction of placental vasculogenesis led to a drastic increase in hypoxic levels of the embryo proper itself.

Hypoxia triggers multiple responses to overcome decreased oxygen availability, including the expression of growth factors required for establishment of a functional circulatory system. HIF proteins can induce VEGF, a growth factor important for angioblast specification and vasculogenesis. ${ }^{43}$ Entailing the reduced amount of $\mathrm{Hif} 1 \alpha$, we saw a reduction in the VEGF expression in KO decidua and placenta, which accounted for the vascularization defects. In line with these data, PIGF, a VEGFrelated factor, was also drastically decreased in $\mathrm{KO}$ placenta but was not reduced in the surrounding decidua. Reduced amounts of PIGF in turn stimulate UNK cell proliferation. This could account for the increased amounts of UNK cells observed in the surrounding decidua of the KO placenta. ${ }^{78}$ Uterine NK cells were further shown to secrete angiogenic factors such as VEGF and PIGF, ${ }^{60}$ balancing the inhibitory effects of the decidual hyperoxia. Furthermore, VEGF is a known survival factor for embryonic stem cells during prolonged hypoxia as well as for hematopoietic stem cells, ${ }^{79,80}$ which are generated among others in the placenta. ${ }^{81}$ In line with these findings, we reported that keratin $\mathrm{Ktyll}^{-/-}$placentas did not only exhibit reduced vasculature but also the vessels that were present were dilated and filled with fewer embryonic blood cells, corresponding to hematopoiesis defects in $\mathrm{Ktyll}^{-/-}$embryos in the yolk sac. ${ }^{9}$

The development of the labyrinth depends on an intensive cross talk between the epithelial trophoblast lineage and the endothelial cells of the allantois. Different receptor knockout studies, including fibroblast growth factor receptor 2 and Frizzeld 5,22,29 as well as various transcription factors JunB, peroxisome proliferator-activated receptor $\gamma$, and transcription factor eb, 18,19,26,27 displayed very similar phenotypes to the $\mathrm{Ktyll}^{-/-}$embryos, which might be linked to keratin expression. JunB, for example, an activator protein 1 transcription factor, can induce $\mathrm{K} 18$ expression in differentiating embryonic stem cells by binding to an enhancer complex in the first intron. ${ }^{82}$ Various kinases were also reported to show vascularization defects in the placenta and the yolk sac when deleted, such as p38 mitogen-activated protein kinase. ${ }^{25}$ We linked keratin deficiency to a reduction of phospho-specific activation of p38 in yolk sacs earlier, ${ }^{9}$ which would suggest that keratins influence these signaling functions in the trophoblast cells of the labyrinth as well.

Important signaling factors expressed in the allantoic endothelial side of the labyrinth contribute to the development of the labyrinth. Mutations in the Notch signaling pathway, for instance, block chorioallantoic branching and prevent proper invagination of the allantois into the placenta. ${ }^{33,35,36}$ This is also the case for angiopoietin 1 and 2, the vascular remodelers and their receptor Tie2. ${ }^{30,31,38,39}$ Defects in yolk sac and placental vascularization defects were also reported for the VEGF receptors, Flk1 and Flt1. ${ }^{32,34,37}$

Increased secretion of sFlt1 into the maternal blood stream is a hallmark of preeclampsia. Keratin $\mathrm{KO}$ embryos seemed to express the common symptoms, defective trophoblast invasion, hypoxia of the embryo, growth retardation, and defective placental vasculature. However, we could not detect an increase in sFLt1 in the maternal serum. The notion that we did not discover preeclampsia may result from the fact that $\mathrm{KO}$ embryos die before the onset of this condition. ${ }^{70,83}$

In summary, we propose that keratins are crucial for regulating the maternal-fetal vascularization through the correct localization of TGCs and the secretion of TGC hormones. Keratin-dependent failure of trophoblast localization and secretory function elicited multiple decidual defects (see Model in Figure 9). On the basis of our data, we suggest that mutations in $\mathrm{K} 8$ or $\mathrm{K} 18$ might be a plausible cause for early pregnancy loss due to decidual hyperoxia.

\section{Acknowledgments}

We thank our colleague Mechthild Hatzfeld for critical input. Also, we thank those colleagues who generously provided antibodies.

\section{References}

1. Fuchs $E$, Cleveland DW: A structural scaffolding of intermediate filaments in health and disease. Science 1998, 279:514-519

2. Irvine AD, McLean WH: Human keratin diseases: the increasing spectrum of disease and subtlety of the phenotype-genotype correlation. $\mathrm{Br} J$ Dermatol 1999, 140:815-828 
3. Magin TM, Reichelt J, Hatzfeld M: Emerging functions: diseases and animal models reshape our view of the cytoskeleton. Exp Cell Res 2004, 301:91-102

4. Omary MB, Coulombe PA, McLean WH: Intermediate filament proteins and their associated diseases. N Engl J Med 2004, 351:2087-2100

5. Betz RC, Planko L, Eigelshoven S, Hanneken S, Pasternack SM Bussow H, Van Den Bogaert K, Wenzel J, Braun-Falco M, Rutten A, Rogers MA, Ruzicka T, Nothen MM, Magin TM, Kruse R: Loss-offunction mutations in the keratin 5 gene lead to Dowling-Degos disease. Am J Hum Genet 2006, 78:510-519

6. Kim S, Wong P, Coulombe PA: A keratin cytoskeletal protein regulates protein synthesis and epithelial cell growth. Nature 2006, 441:362-365

7. Magin TM, Vijayaraj P, Leube RE: Structural and regulatory functions of keratins. Exp Cell Res 2007, 313:2021-2032

8. Margolis SS, Perry JA, Forester CM, Nutt LK, Guo Y, Jardim MJ, Thomenius MJ, Freel CD, Darbandi R, Ahn JH, Arroyo JD, Wang XF Shenolikar S, Nairn AC, Dunphy WG, Hahn WC, Virshup DM, Kornbluth S: Role for the PP2A/B56delta phosphatase in regulating 14-3-3 release from Cdc25 to control mitosis. Cell 2006, 127:759-773

9. Vijayaraj P, Kroeger C, Reuter U, Hartmann D, Magin TM: Keratins regulate yolk sac hematopoiesis and vasculogenesis through reduced BMP-4 signaling. Eur J Cell Biol 2010, 89:299-306

10. Vijayaraj P, Kroger C, Reuter U, Windoffer R, Leube RE, Magin TM: Keratins regulate protein biosynthesis through localization of GLUT1 and -3 upstream of AMP kinase and Raptor. J Cell Biol 2009, 187: 175-184

11. Hesse M, Franz T, Tamai Y, Taketo MM, Magin TM: Targeted deletion of keratins 18 and 19 leads to trophoblast fragility and early embryonic lethality. EMBO J 2000, 19:5060-5070

12. Tamai $\mathrm{Y}$, Ishikawa $T$, Bosl MR, Mori M, Nozaki M, Baribault H, Oshima RG, Taketo MM: Cytokeratins 8 and 19 in the mouse placental development. J Cell Biol 2000, 151:563-572

13. Baribault H, Price J, Miyai K, Oshima RG: Mid-gestational lethality in mice lacking keratin 8. Genes Dev 1993, 7:1191-1202

14. Jaquemar D, Kupriyanov S, Wankell M, Avis J, Benirschke K, Baribault $\mathrm{H}$, Oshima RG: Keratin 8 protection of placental barrier function. J Cell Biol 2003, 161:749-756

15. Cross JC, Nakano H, Natale DR, Simmons DG, Watson ED: Branching morphogenesis during development of placental villi. Differentiation 2006, 74:393-401

16. Bany BM, Cross JC: Post-implantation mouse conceptuses produce paracrine signals that regulate the uterine endometrium undergoing decidualization. Dev Biol 2006, 294:445-456

17. Adelman DM, Gertsenstein M, Nagy A, Simon MC, Maltepe E: Placental cell fates are regulated in vivo by HIF-mediated hypoxia responses. Genes Dev 2000, 14:3191-3203

18. Barak Y, Nelson MC, Ong ES, Jones YZ, Ruiz-Lozano P, Chien KR, Koder A, Evans RM: PPAR gamma is required for placental, cardiac, and adipose tissue development. Mol Cell 1999, 4:585-595

19. Barak Y, Sadovsky Y, Shalom-Barak T: PPAR signaling in placental development and function. PPAR Res 2008, 2008:142082

20. Cowden Dahl KD, Fryer BH, Mack FA, Compernolle V, Maltepe E, Adelman DM, Carmeliet P, Simon MC: Hypoxia-inducible factors 1alpha and 2alpha regulate trophoblast differentiation. Mol Cell Biol 2005, 25:10479-10491

21. Gabriel HD, Jung D, Butzler C, Temme A, Traub O, Winterhager $E$ Willecke K: Transplacental uptake of glucose is decreased in embryonic lethal connexin26-deficient mice. J Cell Biol 1998, 140:1453-1461

22. Ishikawa T, Tamai Y, Zorn AM, Yoshida H, Seldin MF, Nishikawa S, Taketo MM: Mouse Wnt receptor gene Fzd5 is essential for yolk sac and placental angiogenesis. Development 2001, 128:25-33

23. Katschinski DM, Le L, Schindler SG, Thomas T, Voss AK, Wenger RH: Interaction of the PAS B domain with HSP90 accelerates hypoxiainducible factor-1alpha stabilization. Cell Physiol Biochem 2004, 14 351-360

24. Kozak W, Wrotek S, Walentynowicz K: Hypoxia-induced sickness behaviour. J Physiol Pharmacol 2006, 57(Suppl 8):35-50

25. Mudgett JS, Ding J, Guh-Siesel L, Chartrain NA, Yang L, Gopal S, Shen MM: Essential role for p38alpha mitogen-activated protein kinase in placental angiogenesis. Proc Natl Acad Sci U S A 2000 , 97:10454-10459

26. Schorpp-Kistner M, Wang ZQ, Angel P, Wagner EF: JunB is essential for mammalian placentation. EMBO J 1999, 18:934-948
27. Steingrimsson E, Tessarollo L, Reid SW, Jenkins NA, Copeland NG: The bHLH-Zip transcription factor Tfeb is essential for placental vascularization. Development 1998, 125:4607-4616

28. Voss AK, Thomas T, Gruss P: Mice lacking HSP90beta fail to develop a placental labyrinth. Development 2000, 127:1-11

29. Xu X, Weinstein M, Li C, Naski M, Cohen RI, Ornitz DM, Leder P, Deng C: Fibroblast growth factor receptor 2 (FGFR2)-mediated reciprocal regulation loop between FGF8 and FGF10 is essential for limb induction. Development 1998, 125:753-765

30. Suri C, Jones PF, Patan S, Bartunkova S, Maisonpierre PC, Davis S, Sato TN, Yancopoulos GD: Requisite role of angiopoietin-1, a ligand for the TIE2 receptor, during embryonic angiogenesis. Cell 1996 87:1171-1180

31. Maisonpierre PC, Suri C, Jones PF, Bartunkova S, Wiegand SJ, Radziejewski C, Compton D, McClain J, Aldrich TH, Papadopoulos N, Daly TJ, Davis S, Sato TN, Yancopoulos GD: Angiopoietin-2, a natura antagonist for Tie2 that disrupts in vivo angiogenesis. Science 1997 277:55-60

32. Breier G, Clauss M, Risau W: Coordinate expression of vascular endothelial growth factor receptor-1 (flt-1) and its ligand suggests a paracrine regulation of murine vascular development. Dev Dyn 1995 , 204:228-239

33. Duarte A, Hirashima M, Benedito R, Trindade A, Diniz P, Bekman E, Costa L, Henrique D, Rossant J: Dosage-sensitive requirement for mouse DII4 in artery development. Genes Dev 2004, 18:2474-2478

34. Fong GH, Rossant J, Gertsenstein M, Breitman ML: Role of the Flt-1 receptor tyrosine kinase in regulating the assembly of vascular endothelium. Nature 1995, 376:66-70

35. Gale NW, Dominguez MG, Noguera I, Pan L, Hughes V, Valenzuela DM, Murphy AJ, Adams NC, Lin HC, Holash J, Thurston G, Yancopoulos GD: Haploinsufficiency of delta-like 4 ligand results in embryonic lethality due to major defects in arterial and vascular development. Proc Natl Acad Sci U S A 2004, 101:15949-15954

36. Limbourg FP, Takeshita K, Radtke F, Bronson RT, Chin MT, Liao JK: Essential role of endothelial Notch1 in angiogenesis. Circulation 2005, 111:1826-1832

37. Shalaby F, Rossant J, Yamaguchi TP, Gertsenstein M, Wu XF, Breitman ML, Schuh AC: Failure of blood-island formation and vasculogenesis in Flk-1-deficient mice. Nature 1995, 376:62-66

38. Dumont DJ, Gradwohl G, Fong GH, Puri MC, Gertsenstein M, Auerbach A, Breitman ML: Dominant-negative and targeted null mutations in the endothelial receptor tyrosine kinase, tek, reveal a critical role in vasculogenesis of the embryo. Genes Dev 1994, 8:1897-1909

39. Sato TN, Tozawa $Y$, Deutsch U, Wolburg-Buchholz K, Fujiwara $Y$, Gendron-Maguire M, Gridley T, Wolburg H, Risau W, Qin Y: Distinct roles of the receptor tyrosine kinases Tie-1 and Tie-2 in blood vessel formation. Nature 1995, 376:70-74

40. Hustin J, Schaaps JP: Echographic [corrected] and anatomic studies of the maternotrophoblastic border during the first trimester of pregnancy. Am J Obstet Gynecol 1987, 157:162-168

41. Pringle KG, Kind KL, Thompson JG, Roberts CT: Complex interactions between hypoxia inducible factors, insulin-like growth factor-II and oxygen in early murine trophoblasts. Placenta 2007, 28:1147-1157

42. Dunwoodie SL: The role of hypoxia in development of the mammalian embryo. Dev Cell 2009, 17:755-773

43. Ramirez-Bergeron DL, Runge A, Adelman DM, Gohil M, Simon MC HIF-dependent hematopoietic factors regulate the development of the embryonic vasculature. Dev Cell 2006, 11:81-92

44. Caniggia I, Mostachfi H, Winter J, Gassmann M, Lye SJ, Kuliszewski M, Post M: Hypoxia-inducible factor-1 mediates the biological effects of oxygen on human trophoblast differentiation through TGFbeta(3) $\mathrm{J}$ Clin Invest 2000, 105:577-587

45. Nagamatsu T, Fujii T, Kusumi M, Zou L, Yamashita T, Osuga Y, Momoeda M, Kozuma S, Taketani Y: Cytotrophoblasts up-regulate soluble fms-like tyrosine kinase-1 expression under reduced oxygen: an implication for the placental vascular development and the pathophysiology of preeclampsia. Endocrinology 2004, 145:4838-4845

46. Jauniaux E, Watson AL, Hempstock J, Bao YP, Skepper JN, Burton GJ: Onset of maternal arterial blood flow and placental oxidative stress. A possible factor in human early pregnancy failure. Am $J$ Pathol 2000, 157:2111-2122

47. Jauniaux E, Hempstock J, Greenwold N, Burton GJ: Trophoblastic oxidative stress in relation to temporal and regional differences in 
maternal placental blood flow in normal and abnormal early pregnancies. Am J Pathol 2003, 162:115-125

48. Reichelt J, Magin TM: Hyperproliferation, induction of $\mathrm{c}-\mathrm{Myc}$ and 14-3-3sigma, but no cell fragility in keratin-10-null mice. J Cell Sci 2002, 115:2639-2650

49. McManus JF: Histological and histochemical uses of periodic acid Stain Technol 1948, 23:99-108

50. Simmons DG, Natale DR, Begay V, Hughes M, Leutz A, Cross JC Early patterning of the chorion leads to the trilaminar trophoblast cell structure in the placental labyrinth. Development 2008, 135: 2083-2091

51. Anson-Cartwright L, Dawson K, Holmyard D, Fisher SJ, Lazzarini RA Cross JC: The glial cells missing-1 protein is essential for branching morphogenesis in the chorioallantoic placenta. Nat Genet 2000, 25 311-314

52. Colosi P, Thordarson G, Hellmiss R, Singh K, Forsyth IA, Gluckman P Wood WI: Cloning and expression of ovine placental lactogen. Mol Endocrinol 1989, 3:1462-1469

53. Lescisin KR, Varmuza S, Rossant J: Isolation and characterization of a novel trophoblast-specific cDNA in the mouse. Genes Dev 1988 2:1639-1646

54. Lin J, Poole J, Linzer DI: Three new members of the mouse prolactin/ growth hormone family are homologous to proteins expressed in the rat. Endocrinology 1997, 138:5541-5549

55. Basyuk E, Cross JC, Corbin J, Nakayama H, Hunter P, Nait-Oumesmar B, Lazzarini RA: Murine Gcm1 gene is expressed in a subset of placental trophoblast cells. Dev Dyn 1999, 214:303-311

56. Ain R, Tash JS, Soares MJ: Prolactin-like protein-A is a functional modulator of natural killer cells at the maternal-fetal interface. Mol Cell Endocrinol 2003, 204:65-74

57. Muller H, Liu B, Croy BA, Head JR, Hunt JS, Dai G, Soares MJ: Uterine natural killer cells are targets for a trophoblast cell-specific cytokine, prolactin-like protein A. Endocrinology 1999, 140:2711-2720

58. Croy BA, Luross JA, Guimond MJ, Hunt JS: Uterine natural killer cells: insights into lineage relationships and functions from studies of pregnancies in mutant and transgenic mice. Nat Immun 1996, 15:22-33

59. Paffaro VA, Jr., Bizinotto MC, Joazeiro PP, Yamada AT: Subset classification of mouse uterine natural killer cells by DBA lectin reactivity. Placenta 2003, 24:479-488

60. Hanna J, Goldman-Wohl D, Hamani Y, Avraham I, Greenfield C Natanson-Yaron S, Prus D, Cohen-Daniel L, Arnon TI, Manaster I, Gazit R, Yutkin V, Benharroch D, Porgador A, Keshet E, Yagel S, Mandelboim O: Decidual NK cells regulate key developmental processes at the human fetal-maternal interface. Nat Med 2006, 12 : 1065-1074

61. Croy BA, Ashkar AA, Minhas K, Greenwood JD: Can murine uterine natural killer cells give insights into the pathogenesis of preeclampsia? J Soc Gynecol Investig 2000, 7:12-20

62. Soares MJ, Konno T, Alam SM: The prolactin family: effectors of pregnancy-dependent adaptations. Trends Endocrinol Metab 2007, 18:114-121

63. Yadi H, Burke S, Madeja Z, Hemberger M, Moffett A, Colucci F: Unique receptor repertoire in mouse uterine NK cells. J Immunol 2008, 181:6140-6147

64. Baumhueter S, Singer MS, Henzel W, Hemmerich S, Renz M, Rosen $\mathrm{SD}$, Lasky LA: Binding of L-selectin to the vascular sialomucin CD34 Science 1993, 262:436-438

65. Baldwin HS, Shen HM, Yan HC, DeLisser HM, Chung A, Mickanin C, Trask T, Kirschbaum NE, Newman PJ, Albelda SM, et al: Platelet endothelial cell adhesion molecule-1 (PECAM-1/CD31): alternatively spliced, functionally distinct isoforms expressed during mammalian cardiovascular development. Development 1994, 120:2539-2553
66. Ginouves A, Ilc K, Macias N, Pouyssegur J, Berra E: PHDs overactivation during chronic hypoxia "desensitizes" HIFalpha and protects cells from necrosis. Proc Natl Acad Sci U S A 2008, 105:4745-4750

67. Levy AP, Levy NS, Wegner S, Goldberg MA: Transcriptional regulation of the rat vascular endothelial growth factor gene by hypoxia. J Biol Chem 1995, 270:13333-13340

68. Achen MG, Gad JM, Stacker SA, Wilks AF: Placenta growth factor and vascular endothelial growth factor are co-expressed during early embryonic development. Growth Factors 1997, 15:69-80

69. Yancopoulos GD, Davis S, Gale NW, Rudge JS, Wiegand SJ, Holash $\mathrm{J}$ : Vascular-specific growth factors and blood vessel formation. Nature 2000, 407:242-248

70. Kanasaki K, Palmsten K, Sugimoto H, Ahmad S, Hamano Y, Xie L, Parry S, Augustin HG, Gattone VH, Folkman J, Strauss JF, Kalluri R: Deficiency in catechol-O-methyltransferase and 2-methoxyoestradiol is associated with pre-eclampsia. Nature 2008, 453:1117-1121

71. Simmons DG, Fortier AL, Cross JC: Diverse subtypes and developmental origins of trophoblast giant cells in the mouse placenta. Dev Biol 2007, 304:567-578

72. Adamson SL, Lu Y, Whiteley KJ, Holmyard D, Hemberger M, Pfarrer C, Cross JC: Interactions between trophoblast cells and the maternal and fetal circulation in the mouse placenta. Dev Biol 2002, 250:358-373

73. Bordeleau F, Galarneau L, Gilbert S, Loranger A, Marceau N: Keratin 8/18 modulation of protein kinase C-mediated integrin-dependent adhesion and migration of liver epithelial cells. Mol Biol Cell 2010 21:1698-1713

74. Jackson D, Volpert OV, Bouck N, Linzer DI: Stimulation and inhibition of angiogenesis by placental proliferin and proliferin-related protein. Science 1994, 266:1581-1584

75. Toivola DM, Krishnan S, Binder HJ, Singh SK, Omary MB: Keratins modulate colonocyte electrolyte transport via protein mistargeting. J Cell Biol 2004, 164:911-921

76. Ma GT, Linzer DI: GATA-2 restricts prolactin-like protein A expression to secondary trophoblast giant cells in the mouse. Biol Reprod 2000, 63:570-574

77. Ain R, Dai G, Dunmore JH, Godwin AR, Soares MJ: A prolactin family paralog regulates reproductive adaptations to a physiological stressor. Proc Natl Acad Sci U S A 2004, 101:16543-16548

78. Tayade C, Hilchie D, He H, Fang Y, Moons L, Carmeliet P, Foster RA, Croy BA: Genetic deletion of placenta growth factor in mice alters uterine NK cells. J Immunol 2007, 178:4267-4275

79. Brusselmans K, Bono F, Collen D, Herbert JM, Carmeliet P, Dewerchin M: A novel role for vascular endothelial growth factor as an autocrine survival factor for embryonic stem cells during hypoxia. J Biol Chem 2005, 280:3493-3499

80. Gerber HP, Malik AK, Solar GP, Sherman D, Liang XH, Meng G, Hong K, Marsters JC, Ferrara N: VEGF regulates haematopoietic stem cell survival by an internal autocrine loop mechanism. Nature 2002, 417: 954-958

81. Rhodes KE, Gekas C, Wang Y, Lux CT, Francis CS, Chan DN, Conway S, Orkin SH, Yoder MC, Mikkola HK: The emergence of hematopoietic stem cells is initiated in the placental vasculature in the absence of circulation. Cell Stem Cell 2008, 2:252-263

82. Pankov R, Neznanov N, Umezawa A, Oshima RG: AP-1. ETS, and transcriptional silencers regulate retinoic acid-dependent induction of keratin 18 in embryonic cells. Mol Cell Biol 1994, 14:7744-7757

83. Maynard SE, Min JY, Merchan J, Lim KH, Li J, Mondal S, Libermann TA, Morgan JP, Sellke FW, Stillman IE, Epstein FH, Sukhatme VP Karumanchi SA: Excess placental soluble fms-like tyrosine kinase 1 (sFlt1) may contribute to endothelial dysfunction, hypertension, and proteinuria in preeclampsia. J Clin Invest 2003, 111:649-658 